\title{
RELATIONSHIPS BETWEEN LAND USE AND NITROGEN AND PHOSPHORUS CONCENTRATIONS IN BERZE RIVER BASIN
}

\author{
Ieva Siksnane, Ainis Lagzdins \\ Latvia University of Life Sciences and Technologies, Latvia \\ ieva.siksnaane@gmail.com, ainis.lagzdins@1lu.lv
}

\begin{abstract}
According to the latest HELCOM eutrophication assessment excessive inputs of nitrogen and phosphorus to the riverine and marine environments are one of the main reasons for water quality deterioration in the Baltic Sea. Both nitrogen and phosphorus are natural elements in terrestrial and aquatic ecosystems as essential for the plant growth. There are many factors both natural and anthropogenic that impact the amount of excess nutrients discharged in streams and rivers. This research examines how catchment area characteristics in terms of share of different land uses influence nutrient concentrations in water at a sub-basin level. Using the CORINE Land Cover 2018 data and results of Agricultural Runoff Monitoring Programme, as collected in the fifteen Berze river sub-basins during the time period of 2005-2020, the relationships between land use and concentrations of nitrate-nitrogen $\left(\mathrm{NO}_{3}-\mathrm{N}\right)$, ammonium-nitrogen $\left(\mathrm{NH}_{4}-\mathrm{N}\right)$, total nitrogen $(\mathrm{TN})$, orthophosphate-phosphorus $\left(\mathrm{PO}_{4-}\right.$ $\mathrm{P})$, and total phosphorus (TP) were assessed. In general, the results suggest that with increasing proportion of agricultural land in the catchment area the mean $\mathrm{TN}, \mathrm{NO}_{3}-\mathrm{N}, \mathrm{TP}, \mathrm{PO}_{4}-\mathrm{P}$ concentrations in water are expected to increase. Contrary to agricultural land with increasing proportion of forest and semi-natural areas, the mean TN, $\mathrm{NO}_{3}-\mathrm{N}, \mathrm{TP}, \mathrm{PO}_{4}-\mathrm{P}$ concentrations in water decrease. With higher proportion of water bodies in the catchment area, the mean concentrations of $\mathrm{NH}_{4}-\mathrm{N}$ in water decrease as well. The conclusions of this study can be used to evaluate the current situation in the catchment areas where no water quality sampling and hydrology measurements are carried out, as well as for planning purposes of land use change in a given catchment area, which allows to forecast future changes in water quality.
\end{abstract}

Keywords: land use, monitoring, nutrients, concentrations, runoff.

\section{Introduction}

High levels of nutrients, primarily nitrogen and phosphorus, in water bodies may lead to multiple health and environmental problems, such as low levels of oxygen dissolved in the water, increased growth of algae and macrophytes, and blooms of blue-green algae [1]. Nutrients enter a body of water as runoff from a drainage area, which can be characterized by variable natural and anthropogenic factors including hydrologic and weather conditions, topography, and land use $[1 ; 2]$. Due to increasingly demanding regulations the water quality has improved over time, but there are still hot spots in Europe with high nitrate-nitrogen concentrations and understanding the impact of land management on nitratenitrogen concentrations and trends in these critical areas remains difficult [3]. When targeted policies to prevent eutrophication and high levels of nutrients in water bodies are developed, it is essential to take into consideration the contribution of specific sources of nutrients and how the characteristics of land use at the drainage area interact with nutrient levels [4]. Earlier studies conducted at small agricultural catchments have concluded that the share of arable land correlated positively with total nitrogen concentrations [5] and loss [6]. This study aims to investigate how the characteristics of the drainage area influence the concentrations of nutrients (nitrate-nitrogen $\left(\mathrm{NO}_{3}-\mathrm{N}\right)$, ammonium-nitrogen $\left(\mathrm{NH}_{4}-\mathrm{N}\right)$, total nitrogen (TN), orthophosphate-phosphorus $\left(\mathrm{PO}_{4}-\mathrm{P}\right)$, and total phosphorus (TP)) in the water at the sub-basin level as related to the proportion of different land uses in the drainage area.

\section{Materials and methods}

The Berze river basin is located in the central part of Latvia. The river as it flows crosses the municipalities of Auce, Saldus, Dobele, and Jelgava (Fig.1). The Berze river is a tributary of the Svete River and is a part of the Lielupe river basin district, major tributaries include the Bikstupe River, the Blidene river, the Sesava river, the Alave river, the Licupe river, and the Gardene river. The Berze river catchment includes 15 sub-basins (1 to 15 ) with the contributing area of $872.0 \mathrm{~km}^{2}$.

The time frame of this study lasts from 2005 through 2020. The water samples at 15 sub-basins were collected on a monthly basis using a grab sampling approach and tested in an accredited laboratory to detect the concentrations of $\mathrm{NO}_{3}-\mathrm{N}, \mathrm{NH}_{4}-\mathrm{N}, \mathrm{TN}, \mathrm{PO}_{4}-\mathrm{P}$ and $\mathrm{TP}$ in the water. 


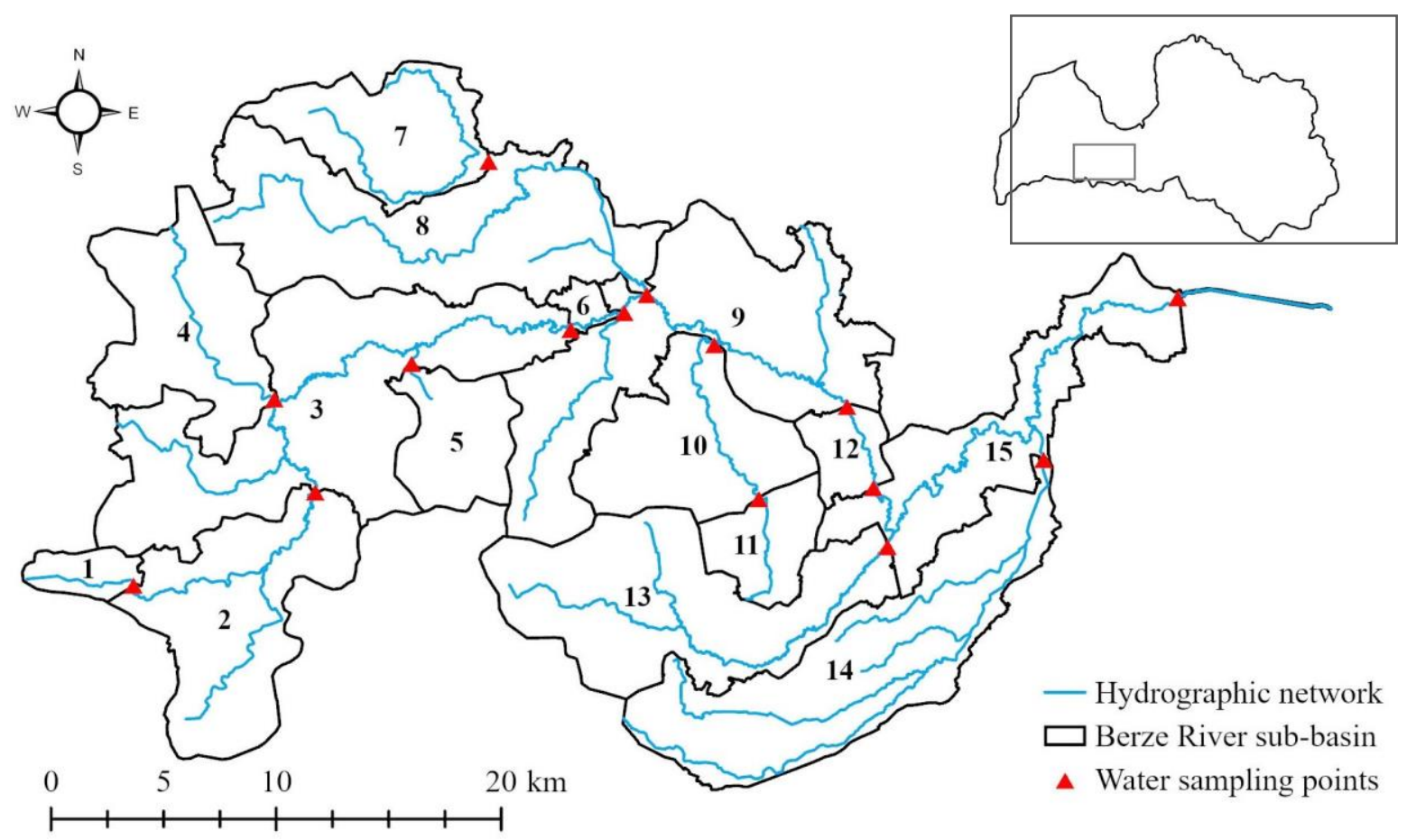

Fig. 1. Location of the Berze river sub-basins [7]

The CORINE (Coordination of Information on the Environment) Land Cover (CLC) inventory was initiated in 1985 by the European Commission's program [8; 9]. The updates have been released in 2000, 2006, 2012, and the latest in 2018. The CLC provides information on the biophysical characteristics of the Earth's surface, as well as its changes [8]. The standard CLC nomenclature includes 44 land cover classes, which are grouped in a three-level hierarchy. The five main categories under the level-one are: 1) artificial surfaces, 2) agricultural areas, 3) forests and semi-natural areas, 4) wetlands, and 5) water bodies [10]. The CLC dataset for the territory of Latvia was used to clip the land use cover for each of the fifteen sub-basins of the Berze river and calculate the share of each land use class for the respective sub-basins according to the nomenclature guidelines [10].

The $\mathrm{NH}_{4}-\mathrm{N}, \mathrm{TP}$ and $\mathrm{TN}$ concentrations are limited in the Latvian legislation through the implementation of the Water Framework Directive. According to the Annex 1 of the "Environmental report for the Lielupe river basin district management plan and flood risk management plan 2016-2021" [11], the Berze river basin consists of three water bodies including L109, L111, and L114 (L109 includes the sub-basins No.14, No.15; L111 consists the sub-basins No.1, No.2, No.3, No.4, No.5, No.6, No.9, No.10, No.11, No.12, No.13; L114 covers the sub-basins No.7, No.8). According to the Annex 2.3 "Characterization of surface water bodies in the Lielupe river basin district" the water body of L109 is indicated as Type 4, while the water bodies of L111 and L114 are described as Type 3. The limits of physico-chemical quality classes for all types of water bodies are defined in the Annex 4.3 of the "Lielupe River Basin District Management Plan for 2016-2021" [11].

Table 1

Limits of physico-chemical quality classes for the types of water bodies within the Berze river basin (indicators in $\mathbf{m g} \cdot \mathrm{L}^{-1}$ )

\begin{tabular}{|c|c|c|c|c|c|c|}
\hline Type & Indicator & High & Good & Moderate & Poor & Bad \\
\hline \multirow{4}{*}{3} & $\mathrm{NH}_{4}-\mathrm{N}$ & $<0.09$ & $0.09-0.12$ & $0.12-0.15$ & $0.15-0.18$ & $>0.18$ \\
\cline { 2 - 7 } & $\mathrm{TN}$ & $<1.8$ & $1.8-2.3$ & $2.3-2.8$ & $2.8-3.3$ & $>3.3$ \\
\cline { 2 - 7 } & $\mathrm{TP}$ & $<0.05$ & $0.05-0.075$ & $0.075-0.100$ & $0.100-0.125$ & $>0.125$ \\
\hline \multirow{3}{*}{4} & $\mathrm{NH}_{4}-\mathrm{N}$ & $<0.16$ & $0.16-0.24$ & $0.24-0.32$ & $0.32-0.40$ & $>0.40$ \\
\cline { 2 - 7 } & $\mathrm{TN}$ & $<2$ & $2.0-3.0$ & $3.0-4.0$ & $4.0-5.0$ & $>5.0$ \\
\cline { 2 - 7 } & $\mathrm{TP}$ & $<0.06$ & $0.06-0.090$ & $0.090-0.135$ & $0.135-0.180$ & $>0.180$ \\
\hline
\end{tabular}


The quality criteria are marked by colors: high quality in blue color, good in green, moderate in yellow, poor in orange and bad in red color.

According to the EU Nitrates Directive (Directive 91/676/EEC) [12] the permitted maximum value of the annual mean concentrations of $\mathrm{NO}_{3}-\mathrm{N}$ in water is $11.3 \mathrm{mg} \mathrm{l}^{-1}$. There are no limiting values determined for the mean annual concentrations of $\mathrm{PO}_{4}-\mathrm{P}$.

\section{Results and discussion}

Mean concentrations of $\mathrm{NO}_{3}-\mathrm{N}, \mathrm{NH}_{4}-\mathrm{N}, \mathrm{TN}, \mathrm{PO}_{4}-\mathrm{P}$ and $\mathrm{TP}$ in all 15 sub-basins were estimated in the research period (Table 1).

Mean concentration and standard deviation of $N$ and $P$ forms $\left(m g \cdot L^{-1}\right)$ in waters

Table 2 of the Berze river sub-basins (2005-2020)

\begin{tabular}{|c|c|c|c|c|c|c|c|c|c|c|}
\hline Indicator & \multicolumn{2}{|c|}{$\mathrm{NO}_{3}-\mathrm{N}$} & \multicolumn{2}{|c|}{$\mathbf{N H}_{4}-\mathbf{N}$} & \multicolumn{2}{|c|}{ TN } & \multicolumn{2}{|c|}{$\mathbf{P O}_{4}-\mathbf{P}$} & \multicolumn{2}{|c|}{ TP } \\
\hline $\begin{array}{c}\text { Sub- } \\
\text { basin No. }\end{array}$ & 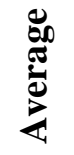 & 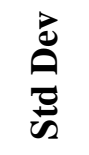 & 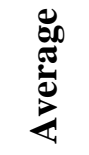 & 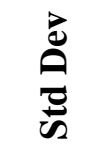 & 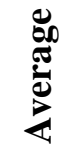 & 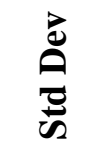 & 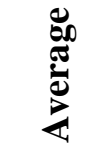 & $\frac{\vec{U}}{\stackrel{D}{0}}$ & 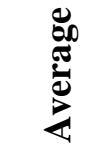 & $\frac{\vec{U}}{\vec{D}}$ \\
\hline 1 & 0.4 & 0.35 & 0.05 & 0.096 & 1.5 & 0.52 & 0.015 & 0.0161 & 0.034 & 0.0200 \\
\hline 2 & 1.3 & 1.43 & 0.06 & 0.083 & 2.3 & 1.51 & 0.010 & 0.0093 & 0.025 & 0.0134 \\
\hline 3 & 1.3 & 1.35 & 0.08 & 0.136 & 2.2 & 1.42 & 0.021 & 0.0244 & 0.039 & 0.0285 \\
\hline 4 & 1.1 & 0.98 & 0.06 & 0.083 & 2.0 & 1.06 & 0.020 & 0.0151 & 0.039 & 0.0195 \\
\hline 5 & 0.7 & 0.83 & 0.26 & 0.218 & 2.0 & 0.92 & 0.007 & 0.0128 & 0.019 & 0.0156 \\
\hline 6 & 1.3 & 1.35 & 0.08 & 0.076 & 2.2 & 1.38 & 0.013 & 0.0104 & 0.029 & 0.0138 \\
\hline 7 & 3.4 & 3.36 & 0.12 & 0.136 & 4.2 & 3.42 & 0.035 & 0.0262 & 0.053 & 0.0290 \\
\hline 8 & 3.0 & 2.58 & 0.12 & 0.174 & 3.9 & 2.56 & 0.039 & 0.0346 & 0.058 & 0.0390 \\
\hline 9 & 1.7 & 1.55 & 0.07 & 0.072 & 2.5 & 1.61 & 0.025 & 0.1520 & 0.040 & 0.0179 \\
\hline 10 & 1.0 & 1.31 & 0.04 & 0.067 & 2.0 & 1.33 & 0.007 & 0.0059 & 0.018 & 0.0087 \\
\hline 11 & 1.3 & 2.74 & 0.14 & 0.225 & 3.0 & 2.74 & 0.033 & 0.0485 & 0.051 & 0.0577 \\
\hline 12 & 2.1 & 1.60 & 0.14 & 0.484 & 3.0 & 1.86 & 0.046 & 0.0757 & 0.063 & 0.0848 \\
\hline 13 & 1.9 & 1.50 & 0.04 & 0.058 & 2.6 & 1.55 & 0.016 & 0.0135 & 0.025 & 0.0136 \\
\hline 14 & 4.6 & 4.03 & 0.07 & 0.101 & 5.5 & 4.18 & 0.058 & 0.0388 & 0.073 & 0.0427 \\
\hline 15 & 2.1 & 1.82 & 0.05 & 0.062 & 2.9 & 1.88 & 0.038 & 0.0263 & 0.053 & 1.0930 \\
\hline
\end{tabular}

The mean annual concentrations of $\mathrm{NO}_{3}-\mathrm{N}$ do not exceed the limiting value set by the EU Nitrates directive. The quality classes for $\mathrm{NH}_{4}-\mathrm{N}, \mathrm{TN}$ and TP are represented by colors in Table 2 .

The coefficient of variation is a statistical measure of the dispersion of data points in a data series around the mean, the coefficient of variation represents the ratio of the standard deviation to the mean [13], for the mean concentrations of nutrients during the study period the following coefficients of variations were detected: $62 \%$ for $\mathrm{NO}_{3}-\mathrm{N}, 63 \%$ for $\mathrm{NH}_{4}-\mathrm{N}, 38 \%$ for TN, $60 \%$ for $\mathrm{PO}_{4}-\mathrm{P}, 40 \%$ for TP.

The minimum $\mathrm{NO}_{3}-\mathrm{N}$ and $\mathrm{TN}$ concentration values are observed in the sub-basin No.1, $\mathrm{NH}_{4}-\mathrm{N}$ and $\mathrm{TP}$ in the sub-basin No.10, $\mathrm{PO}_{4}-\mathrm{P}$ in the sub-basin No.5. The maximum $\mathrm{NO}_{3}-\mathrm{N}, \mathrm{TN}, \mathrm{PO}_{4}-\mathrm{P}, \mathrm{TP}$ values are observed in the sub-basin No.14, while for $\mathrm{NH}_{4}-\mathrm{N}$ in the sub-basin No.5.

To assess the impact of land use in each of the sub-basin areas, the percentage of CLC class of the total sub-basin area was estimated (Table 3).

No artificial surfaces in the sub-basins No.1, No.5 and No.11 were determined, the highest proportion of this land use was detected in the sub-basin No.12 (2.88\%). The highest proportions of agricultural areas were calculated for the sub-basin No.14 (83.38\%), while the highest shares of forest and semi-natural areas were observed in the sub-basin No.11 (70.20\%). No wetlands were detected in the sub-basins No.7, No.13, No.14, meanwhile the highest proportion of wetlands were noticed in the sub-basin No.1. No water bodies were detected in the sub-basins No.1, No.2., and No.11. 
Land use of the Berze river sub-basins (\%) by CLC 2018 nomenclature

Table 3

\begin{tabular}{|c|c|c|c|c|c|}
\hline $\begin{array}{c}\text { CLC class } \\
\text { /Sub-basin No. }\end{array}$ & $\begin{array}{c}\text { Artificial } \\
\text { surfaces, \% }\end{array}$ & $\begin{array}{c}\text { Agricultural } \\
\text { areas, \% }\end{array}$ & $\begin{array}{c}\text { Forest and semi- } \\
\text { natural areas, \% }\end{array}$ & $\begin{array}{c}\text { Wetlands, } \\
\text { \% }\end{array}$ & $\begin{array}{c}\text { Water bodies, } \\
\text { \% }\end{array}$ \\
\hline 1 & 0.00 & 10.42 & 61.87 & 27.71 & 0.00 \\
\hline 2 & 0.84 & 44.42 & 51.45 & 3.29 & 0.00 \\
\hline 3 & 1.55 & 46.05 & 48.08 & 2.12 & 2.20 \\
\hline 4 & 1.78 & 36.09 & 59.63 & 1.50 & 1.01 \\
\hline 5 & 0.00 & 28.83 & 51.78 & 2.10 & 17.30 \\
\hline 6 & 1.57 & 46.66 & 47.41 & 2.09 & 2.27 \\
\hline 7 & 0.95 & 63.83 & 35.07 & 0.00 & 0.15 \\
\hline 8 & 2.30 & 58.73 & 38.18 & 0.23 & 0.55 \\
\hline 9 & 2.04 & 50.65 & 44.30 & 1.65 & 1.35 \\
\hline 10 & 2.03 & 38.01 & 57.06 & 2.42 & 0.49 \\
\hline 11 & 0.00 & 27.94 & 70.20 & 1.86 & 0.00 \\
\hline 12 & 2.88 & 50.57 & 43.61 & 1.62 & 1.33 \\
\hline 13 & 1.03 & 46.58 & 51.48 & 0.00 & 0.90 \\
\hline 14 & 2.65 & 83.38 & 13.54 & 0.00 & 0.44 \\
\hline 15 & 2.85 & 56.31 & 38.59 & 1.16 & 1.09 \\
\hline
\end{tabular}

A

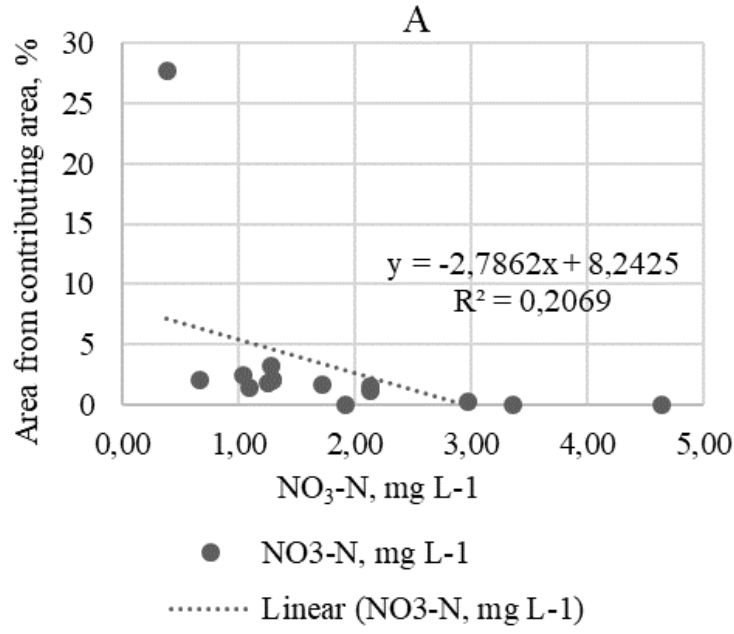

B

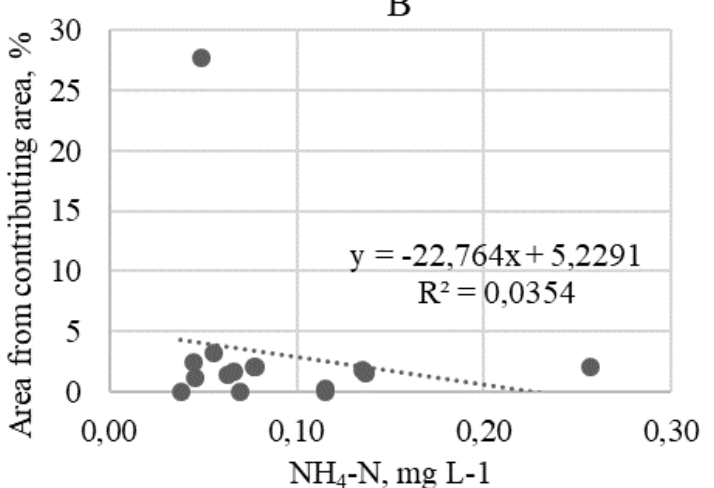

- NH4-N, mg L-1

........ Linear (NH4-N, mg L-1)

Fig. 2. Scatterplot of $\mathrm{NO}_{3}-\mathrm{N}$ concentrations $\left(\mathrm{mg}^{-} \mathbf{L}^{-1}\right)$ vs. percentage of wetlands $(\mathrm{A})$ and $\mathrm{NH}_{4}-\mathrm{N}$ concentrations $\left(\mathrm{mg} \cdot \mathrm{L}^{-1}\right)$ vs. percentage of water bodies $(B)$ in the Berze river sub-basins

The negative and moderately close correlation of -0.46 between the mean concentrations of $\mathrm{NO}_{3}-\mathrm{N}$ and wetlands was detected, this study shows that as the percentage of wetlands in the sub-basin decreases, the concentrations of $\mathrm{NO}_{3}-\mathrm{N}$ increase (Fig.2 A).

The forest and semi-natural areas are dominant in both minimum (sub-basin No.5) and maximum (sub-basin No.10) values for the mean concentrations of $\mathrm{NH}_{4} \mathrm{~N}$, but in the sub-basin with a higher proportion of water bodies (sub-basin No.5 has $17.30 \%$ of water bodies) the $\mathrm{NH}_{4}-\mathrm{N}$ concentration is lower (Fig.2 B). It can be explained by a close, positive correlation between the land use of water bodies and $\mathrm{NH}_{4}-\mathrm{N}$ concentrations (correlation coefficient 0.80 ).

The regression equations presented in Fig.2A and Fig.2B are strongly affected by the extreme values of land use distribution in several sub-basins. The extreme value of $\mathrm{NO}_{3}-\mathrm{N}$ (Fig.2 A) is caused by a disproportionate share of wetlands in the sub-basin No.1 (27.7\%). The extreme value of $\mathrm{NH}_{4}-\mathrm{N}$ (Fig.2 B) represents the sub-basin No.5, where the share of water bodies is much higher when compared with other sub-basins, because this sub-basin includes Zebrus Lake.

The maximum mean concentrations of $\mathrm{TN}$ and $\mathrm{NO}_{3}-\mathrm{N}$ were detected in the sub-basin No.14, where $83.38 \%$ of all contributing area is the agricultural land. Positive, close correlation between the agricultural land and mean concentrations of $\mathrm{TN}$ (correlation coefficient 0.85 for $\mathrm{TN}, 0.92$ for $\mathrm{NO}_{3}-\mathrm{N}$ ) 
were observed. Preliminary studies of Delkash et.al., Huang et.al., Sylaios et.al. [14-16] confirm the conclusions of this study that as the percentage of agricultural areas increases, concentrations of TN and $\mathrm{NO}_{3}-\mathrm{N}$ increase.

A

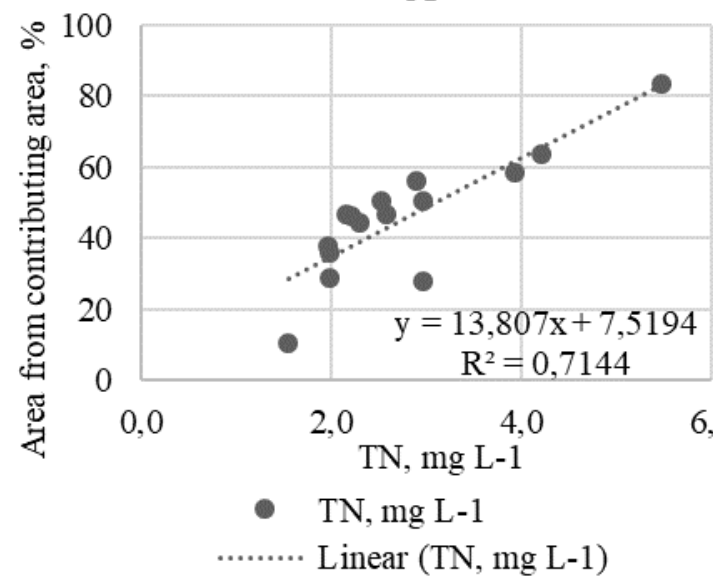

B

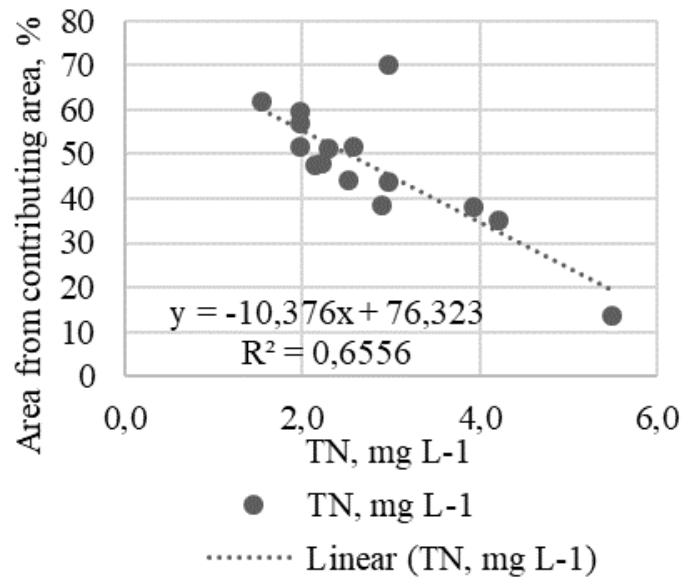

Fig. 3 Scatterplot of $\mathbf{T N}$ concentrations $\left(\mathbf{m g} \cdot \mathbf{L}^{-1}\right)$ vs. percentage of agricultural area (A) and forest and semi-natural areas $(B)$ in the Berze river sub-basins

The minimum mean concentrations of $\mathrm{TN}$ and $\mathrm{NO}_{3}-\mathrm{N}$ in the sub-basin No.1 were detected, where the forest and semi-natural areas are the dominant types of land use (61.87\%). Negative, close correlation between the forest and semi-natural areas and mean concentrations of TN (correlation coefficient -0.81) were observed. In the sub-basin No.1 large proportion $(27.71 \%)$ of wetland area results in the negative, moderately close correlation between the wetland area and concentrations of nitrogen (correlation coefficient for $\mathrm{TN}-0.42$, for $\mathrm{NO}_{3}-\mathrm{N}-0.45$ ). The previous study of Huang et.al. [15] agrees with the results of this study - as the percentage of the forest and semi-natural areas is decreasing, the concentrations of $\mathrm{TN}$ and $\mathrm{NO}_{3}-\mathrm{N}$ increase.

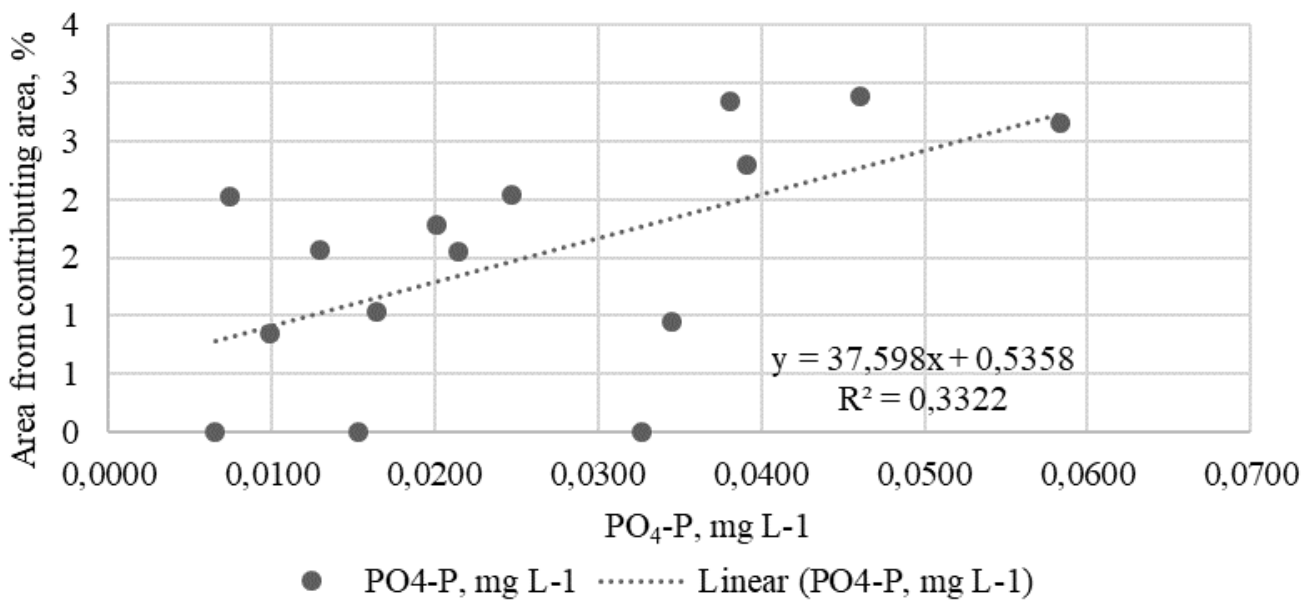

Fig. 4. Scatterplot of $\mathbf{P O}_{4}-\mathbf{P}\left(\mathbf{m g} \cdot \mathbf{L}^{-1}\right)$ vs. percentage of artificial surfaces in the Berze river sub-basins

The positive, moderately close correlation between the mean concentrations of TP and $\mathrm{PO}_{4}-\mathrm{P}$ and artificial surfaces (correlation coefficient 0.52 for TP, 0.58 for $\mathrm{PO}_{4}-\mathrm{P}$ ) was detected, it can be concluded that as the proportion of artificial areas increases, the concentration of TP and $\mathrm{PO}_{4}-\mathrm{P}$ also increases. The study conducted by Camara et.al. indicates that urban development activities had a greater impact on the water quality through altering hydrological processes [17]. The investigations of Ahean et.al. confirm this statement, as the results show, where the lack of correlation between the population density and nutrient load was accessed, as long as no wastewater treatment plant is built in the sub-basin [18]. 
A

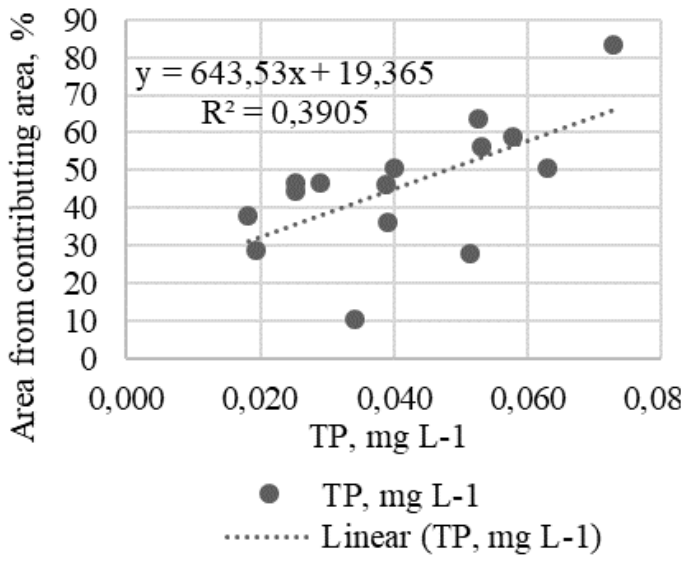

B

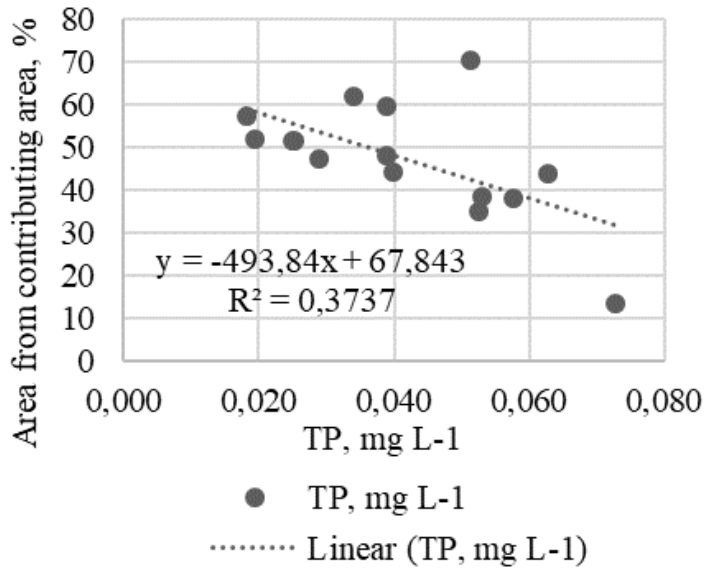

Fig. 5. Scatterplot of $T P\left(\mathrm{mg} \cdot \mathrm{L}^{-1}\right)$ vs. percentage of agricultural areas (A) and forest and semi-natural areas $(B)$ in the Berze river sub-basins

The maximum mean concentrations of TP and $\mathrm{PO}_{4}-\mathrm{P}$ were detected in the sub-basin No.14, where $83.38 \%$ of all contributing area is the agricultural land, positive, moderately close correlation between the agricultural areas and mean concentrations of TP (correlation coefficient of 0.62 for TP and 0.70 for $\mathrm{PO}_{4}-\mathrm{P}$ ), a strong resemblance to $\mathrm{TN}$ and $\mathrm{NO}_{3}-\mathrm{N}$ in this study - as the percentage of agricultural areas increase, the concentration of TP and $\mathrm{PO}_{4}-\mathrm{P}$ increases. The minimum mean concentrations of TP were detected in the sub-basin No.10, where $57.06 \%$ of all contributing area is the forest and semi-natural areas (correlation coefficient of 0.61). As the percentage of forest and semi-natural areas is decreasing, the concentrations of TP and $\mathrm{PO}_{4}-\mathrm{P}$ increase. The study of Huang et.al. and Ahean et.al. $[15 ; 18]$ confirms the results mentioned above, as the relationship between TP and $\mathrm{PO}_{4}-\mathrm{P}$ concentrations and land use were detected.

\section{Conclusions}

1. The close and positive correlation between the percentage of water bodies in the contributing area and mean concentrations of $\mathrm{NH}_{4}-\mathrm{N}$ was detected with the correlation coefficient of 0.80 .

2. With increasing proportion of agricultural land in the sub-basin the concentration of $\mathrm{TN}, \mathrm{NO}_{3}-\mathrm{N}$, $\mathrm{TP}, \mathrm{PO}_{4}-\mathrm{P}$ are expected to increase with the correlation coefficients of $0.85 ; 0.92 ; 0.62 ; 0.70$, respectively.

3. With decreasing proportion of forest and semi-natural land in the sub-basin the concentrations of $\mathrm{TN}, \mathrm{NO}_{3}-\mathrm{N}, \mathrm{TP}, \mathrm{PO}_{4}-\mathrm{P}$ are expected to increase (the correlation coefficient for $\mathrm{TN}$ was 0.81 , while for TP it was 0.61 ).

4. It is likely that the increasing proportion of artificial surfaces in the sub-basin will lead to increase in $\mathrm{TP}$ and $\mathrm{PO}_{4}-\mathrm{P}$ concentrations with the correlation coefficients of 0.52 and 0.58 , respectively.

The results of this study can be used to determine how land use planning and land use changes would affect the water quality at a sub-basin scale with similar land use distribution elsewhere in Latvia.

\section{References}

[1] Diaz R.J., Rosenberg R., 2008. Spreading dead zones and consequences for marine ecosystems. Science, vol. 321, 2008, pp. 926-929.

[2] Romero E., Garnier J., Lassaletta L., Billen G., Le Gendre R., Riou P., Cugier P. Large-scale patterns of river inputs in southwestern Europe: seasonal and interannual variations and potential eutrophication effects at the coastal zone. Biogeochemistry, vol. 113, 2013, pp. 481-505.

[3] Bouraoui F., Malagó A. Trend Analysis of Nitrate Concentration in Rivers in Southern France. Water, vol. 12, 2020, pp. 1-21.

[4] Abell J.M., Özkundakci D., Hamilton D.P., Miller S.D. Relationships between land use and nitrogen in New Zealand lakes. Marine and Freshwater Research, 62(2), 2011, pp.162-175. 
[5] Kyllmar K., Carlsson C., Gustafson A., Ulen B., Johnsson H. Nutrient discharge from small agricultural catchments in Sweden: Characterisation and trends. Agriculture, Ecosystems and Environment, vol. 115, 2006, pp. 15 - 26.

[6] Jansons V., Busmanis P., Dzalbe I., Kirsteina D. Catchment and drainage field nitrogen balances and nitrogen loss in three agriculturally influenced Latvian watersheds. European Journal of Agronomy, vol. 20, 2003, pp. 173 - 179.

[7] Geospatial information of Latvia University of Life Sciences and Technologies and State limited Liability Company "Latvian Environment, Geology and Meteorology Centre".

[8] Bielecka E., Jenerowicz A. Intellectual Structure of CORINE Land Cover Research Applications in Web of Science: A Europe-Wide Review. Remote sensing, 11(17), 2019, pp. 1-24.

[9] Büttner G., Maucha G., Biro M.S.T., Kosztra B., Pataki R., Petrik O. National Land Cover Database at Scale 1:50 000 In Hungary. EARSeL eProceedings 3, 2004, pp. 323-330.

[10] The CORINE Land Cover (CLC) nomenclature [online] [09.03.2021]. Available at: http://map.lgia.gov.lv/index.php?lang=0\&cPath=4_17\&txt_id=131.

[11] Environmental report for the Lielupe river basin district management plan and flood risk management plan 2016-2021 plan [online]. [16.04.2021]. Available at: https://www.meteo.lv/lapas/vide/udens/udens-apsaimniekosana-/upju-baseinu-apgabaluapsaimniekosanas-plani-/upju-baseinu-apgabalu-apsaimniekosanas-plani-un-pludu-riskaparvaldiba?id=1107\&nid $=424$.

[12] Directive 91/676/EEC of the Council of the European Communities of 12 December 1991 concerning the protection of waters against pollution caused by nitrates from agricultural sources. Official Journal of European Union 1991: L 375/1.

[13] Heyes A., Westfall P. Coefficient of Variation (CV) [online] [09.03.2021]. Available at: https://www.investopedia.com/terms/c/coefficientofvariation.asp.

[14] Delkash M., Al-Faraj F.A.M., Scholz M. Impacts of Anthropogenic Land Use Changes on Nutrient Concentrations in Surface Waterbodies: A Review. Clean - Soil, Air, Water 46 (5), 2018, pp. 1-10.

[15] Huang J., Zhan J., Yan H., Wu F., Deng X. Evaluation of the Impacts of Land Use on Water Quality: A Case Study in The Chaohu Lake Basin. The Scientific World Journal, vol. 2013, 2013, pp. 1-7.

[16] Sylaios G., Stamatis N., Kallianiotis A., Vidoris P. Monitoring Water Quality and Assessment of Land-Based Nutrient Loadings and Cycling in Kavala Gulf. Water Resources Management vol.19, 2005, pp. 713-735.

[17] Camara M., Jamil N.R., Abdullah A.F.B. Impact of land uses on water quality in Malaysia: a review. Ecological Processes 8, 2019, pp. 1-15.

[18] Ahean D.S., Sheibley R.W., Dahlgren R.A., Anderson M., Johnson J., Tate K.W. Land use and land cover influence on water quality in the last free-flowing river draining the western Sierra Nevada, California. Journal of Hydrology vol.313, issue 3-4, 2005, pp. 234-247. 